\title{
UTILIZATION OF CROP RESIDUES AND AGRO-INDUSTRIAL BY-PRODUCTS AS COMPLETE DIETS FOR WEST AFRICAN DWARF SHEEP AND GOATS
}

\author{
E.A. ADEBOWALE AND A.A. TAIWO \\ Institute of Agricultural Research and Training Obafemi Awolowo University, P.M.B. 5029, \\ Ibadan Nigeria.
}

Received 23 January 1995, Accepted 25 June 1996

\section{ABSTRACT}

Two experiments consisting of three dietary

treatments each were conducted on the use of crop residues and agro-industrial wastes for formulating complete diets for growing West African dwarf sheep and goats. Growth performance and digestibility studies were carried out with the animals. In experiment I Crude proten $(C P)$, ash and gross energy levels increased from diet 1 to diet 3 while the crude fibre contents decreased progressively. Sheep consumed more nutrients $(P<0.01)$ than goats. In the sheep, the highest dry matter intake (DMI) was on diet $2(74.1 \mathrm{~g} / \mathrm{kgw} 0.75)$. However, the intakes of $C P$ and energy on diets 2 and 3 were similar (P1).05). Energy intake was highest in diet 3 for goats, while DMI $\left(47.6 \mathrm{~g} / \mathrm{kgW}^{0.75}\right)$ was comparable $(P>0.05)$ to those on diets 1 and $2\left(50.5\right.$ and $45.0 \mathrm{~g} / \mathrm{kg} \quad W^{0.75}$ respectively. Sheep and goats digested DM, CP and energy similarly $(P>0.05)$. Diet 3 was the most digestible $(P<0.01)$ for energy in both species. Digestibility of DM and CP was best in diet 3 for the sheep. The highest $(P<0.05)$ weight gain of $60.3 \mathrm{~g} /$ day was for sheep on diet 3 . The best feed conversion efficiency ( $\mathrm{FCE}$ ) was also recorded for the same diet for sheep (10.0\%) and goats (9.2\%). In Experiment 2, crude protein levels also increased from diets 1 to diet 3 while crude fibre decreased from diets 1 to 3 . Concentrations of $\mathrm{HCN}(16.7$ and $19.3 \mathrm{mg} / \mathrm{kg}$ for diets 1 and 2 respectively) were low. Sheep consumed more $(\mathrm{P}<0.05)$ DM than goats $(83.8$ and $79.5 \mathrm{~g} / \mathrm{kg} \mathrm{w}^{0.75}$ respectively) while $C P$ was consumed similarly $(P>0.05)$. Goats digested DM $(68.2 \%$ better $(P<0.05)$ than sheep $(59.6 \%)$. Diets did not influence $(P>0.05)$ the $D M$ digestibility within the two species. The highest $(P<0.05)$ weight changes were recorded on diet 3 for sheep and goats (112.4 and 55.2 $/$ /day

respectively). Diets 2 and 3 had comparable $(P>0.05)$ FCE in sheep while that of diet 3 $(9.9 \%)$ was better $(P<0.01)$ among the goats. The results show that some of the diets could be productive for commercial small ruminant production.

Keywords: Crop residue, agro-industrial waste utilization, complete diets, small ruminants.

\section{INTRODUCTION}

The scavenging image of small ruminants cannot be relied on to provide adequate nutrients for optimal livestock production. Thus it is important to ensure adequate feeding in order to enhance the productivity of the stock. The abundancy of crop residues and agro-industrial by products make them cheap sources of nutrients for ruminants. Nevertheless, they are generally low in nutrients (Nicolson, 1984). Various strategies have been adopted in improving their nutrients and utilization. One of such is by treatment to reduce the negative influence of lignin on the utilization of complex carbohydrates (Jackson, 1977; Adebowale, 1985, 1989) while the other is by supplementation to provide the most limiting nutrients e.g. rumen degradable protein, rumen by pass protein or degradable carbohydrate (Preston, 1985; Alhassan, 1988).

Balancing of the nutrients that provide the major building blocks for tissue synthesis and milk production should be the primary concern of the nutritionist (Leng, 1990). This can be achieved by careful blending of the crop residues to meet the nutrient requirements of ruminant livestock. Some studies have been conducted in which crop residues e.g. cowpea husk, maize cob, yam peels and plantain peels partly replace maize in the diets of ruminants (Adebowale, 1981; 1982.
\end{abstract}


Thus this study aims at determing the suitability of crop residues and agro-industrial by-products as complete diets for growing West African dwarf sheep and goats. about $2000 \mathrm{kcal} \mathrm{ME} / \mathrm{kgDM}$ and protein levels from 9 to $15 \%$. Six of the diets were selected for experimentation. The feeds were tested in threes.

TABLE 1 COMPOSITION OF THE COMPLETE DIETS

\begin{tabular}{|c|c|c|c|c|c|c|}
\hline EXPERIMENTS & & 1 & & & 2 & \\
\hline DIETS & 1 & 2 & 3 & 1 & 2 & 3 \\
\hline $\begin{array}{l}\text { INGREDIENTS } \\
\text { Maize cobs } \\
\text { Cassava peels } \\
\text { Rice husk } \\
\text { Plantain peels } \\
\text { Maize offals } \\
\text { Brewers dried grains } \\
\text { Soyabean hulls } \\
\text { Palm kernel cake } \\
\text { Cotton seed cake } \\
\text { Wheat offals } \\
\text { Gliricidia leaves } \\
\text { Groundnut haulms } \\
\text { Poutry litter } \\
\text { Urea } \\
\text { Bone meal } \\
\text { Salt } \\
\text { Vitamin-mineral premix } \\
\end{array}$ & $\begin{array}{l}43.2 \\
10.8 \\
- \\
- \\
15.5 \\
13.5 \\
\vdots \\
i 5.0 \\
- \\
1.5 \\
0.5 \\
\end{array}$ & $\begin{array}{l}8.2 \\
30.0 \\
2.2 \\
\overline{20.0} \\
- \\
10.0 \\
i 2.6 \\
15.0 \\
\vdots \\
1.5 \\
0.5 \\
-\end{array}$ & $\begin{array}{l}29.5 \\
- \\
13.6 \\
20.0 \\
\dot{8} .5 \\
- \\
i 0.4 \\
i 5.0 \\
1.0 \\
1.5 \\
0.5 \\
\end{array}$ & $\begin{array}{l}12.5 \\
30.0 \\
40.0 \\
\vdots \\
7.0 \\
8.0 \\
\vdots \\
\vdots \\
\vdots \\
\vdots \\
1.5 \\
0.5 \\
0.5\end{array}$ & $\begin{array}{l}21.5 \\
20.0 \\
31.0 \\
10.0 \\
5.0 \\
10.0 \\
\vdots \\
- \\
- \\
1.5 \\
0.5 \\
0.5\end{array}$ & $\begin{array}{l}17.0 \\
7.0 \\
\vdots \\
10.0 \\
11.5 \\
10.0 \\
42.0 \\
- \\
- \\
1.5 \\
0.5 \\
0.5 \\
\end{array}$ \\
\hline & 100 & 100 & 100 & 100 & 100 & 100 \\
\hline
\end{tabular}

TABLE 2: CHEMICAL COMPOSITION OF DIETS (DRY MATTER BASIS)

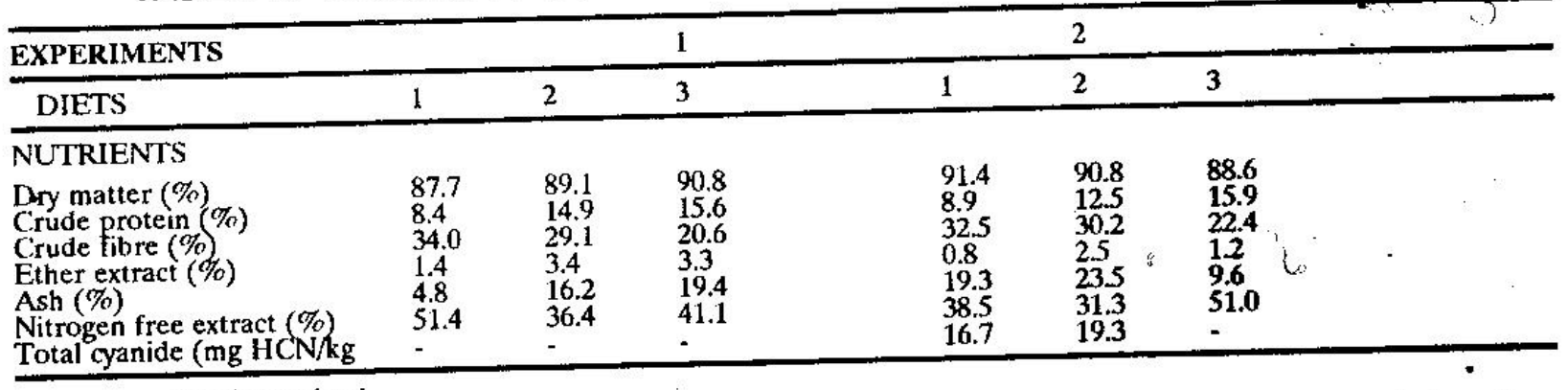

- Not determined.

\section{MATERIALS AND METHODS}

About 44 different types of crop residues which could be sources of nutrients were composited. They were selected based on such criteria as: cost/unit, availability, ease of harvesting/collection, nutritional limitations, and toxicological consideration.

The by-products were analysed for their proximate composition. Nutrient requirement were specified for different classes of sheep and goats. Linear programming by computer analysis was used to formulate about 50 different least cost diets for growing small ruminants. The diets had energy density of
Table 1 shows the composition of the diets used in experiments 1 and 2. Some of the ingredients were dried and ground in a hammer mill before mixing with the others in the feeds. The diet formed the sole feeds offered the animals without any other supplement. Four male West African dwarf (WAD) goats and four male WAD sheep 12 15 months of age with average initial body , weights of about $8.1 \mathrm{~kg}$ and $15.3 \mathrm{~kg}$ (Experiment 1) and $11.0 \mathrm{~kg}$ and $15.4 \mathrm{~kg}$ (Experiment 2) respectively were randomly assigned to each diet for the feeding trials. During the digestibility studies, 2 goats and 2 sheep were alloted to each diet. Prior to the commencement of the experiments, the 
Jnimals were dewormed with an anthelmithic yrug "systamex" and dipped in an acricicide oiution: asuntol against ectoparasites. The vimais were offerea the diet at Mtowon in sed troughs provided in individual pens. Mater was also made available ad ibioum. Vood shavings was used as litter ior the floor a the pens. This was changed regulariy.

The animals were let out in an enclosed arch, without access to any feed, to exercise teir body and received direct rays of sun for a aw hours once a week. Data collected were aalysed using a $2 \times 3$ factorial arrangement. The two species of livestock; sheep and goats vere the two groups while the three diets ormed the sub-groups. Analysis of data was arried out using analysis or variance scinnique (Steel and Torrie, 1980).

The enering trials comprised the growtin rin and the digestibility study. The growth ihdse lasted for twelve weeks with 2 weeks for

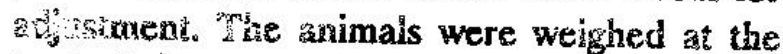
thenting of the experiment and thereafter Q wes weekly in order to estimate weight chasged. Know amounts of the feeds were offered daily in the morning to each animal. The remnants were weighed the following morning to extimate feed intake.

Digestibility study compriced a 2 week preliminary period and a week of collection. The animais were housed in individual metabolism cages with facilities for separate collection of aeces and urine. The animals were weighed at the beginning and at the end of the digestibility study. The diets were offered in feed iroughs and water was provided. The daily feacal output of each animal was separately weighed during the collection period. Samples of the feed and feaces were taken daily for dry matter analysis and bulked for the collection period prior to ther chemical analysis.

Froximate analysis of feed and faeces was sarried out by the A.O.A.C. (1980) methods. Ty matter of samples was determined in an wen al $105^{\circ}$ for 48 hours. Nitrogen determination was by the micro kjeldahl method, white the soxhlet extraction procedure was used for ether extraction. Crude fibre was determined by aiternate refluxing with weak

TABLE S: WHAKE OF NUTRIENTS BY WAD SHEEP AND GOATS FROM THE DIETS (g/kg $\left.W^{0.75}\right)$

EXPERIMENT ।

\begin{tabular}{|c|c|c|c|c|c|c|c|}
\hline \multirow{2}{*}{$\begin{array}{l}\text { SPECIISS } \\
\text { DIETS }\end{array}$} & \multicolumn{3}{|c|}{ SHEEP } & \multicolumn{3}{|c|}{ GOATS } & \multirow{2}{*}{$\begin{array}{l}\text { LEVEL OF } \\
\text { SIGNIFICANCE }\end{array}$} \\
\hline & 1 & 2 & 3 & 1 & 2 & 3 & \\
\hline$\underset{X}{\text { Dry matter intake }}$ & $60.9^{c}$ & $\begin{array}{l}74.1^{2} \\
68.0^{\circ}\end{array}$ & $69.0^{b}$ & $50.5^{\mathrm{a}}$ & $45.0^{b}$ & $47.6^{36}$ & $0.05^{*}$ \\
\hline $\begin{array}{l}\text { Crude protein } \\
\text { intake } \\
\qquad \mathrm{X}\end{array}$ & $5.1^{b}$ & $91.8^{\circ}$ & $10.8^{a}$ & $4.2^{\mathrm{c}}$ & $\begin{array}{l}6.7^{b} \\
6.1^{b}\end{array}$ & $7.5^{\mathrm{a}}$ & $\begin{array}{l}0.01^{*} \\
0.01^{*}\end{array}$ \\
\hline $\begin{array}{c}\begin{array}{l}\text { Energy intakf } \\
(\mathrm{kcal} / \mathrm{kgw} \\
\mathrm{x}\end{array} \\
\end{array}$ & $262.3^{b}$ & $\begin{array}{l}409.5^{0} \\
355.7^{a} \\
\end{array}$ & $395.3^{a}$ & $217.2^{a}$ & $\begin{array}{l}248.6^{b} \\
245.9^{b}\end{array}$ & $271.9^{\mathrm{a}}$ & $\begin{array}{l}0.01^{* *} \\
0.01^{* *}\end{array}$ \\
\hline
\end{tabular}

EXPERIMENT 2

\begin{tabular}{|c|c|c|c|c|c|c|c|}
\hline $\begin{array}{l}\text { SPECLES } \\
\text { DIETS } \\
\end{array}$ & $1 * *$ & $\begin{array}{l}\text { SHEEP } \\
2\end{array}$ & 3 & ${ }_{1 * *}^{\text {GOATS }}$ & - & 3 & \\
\hline Dry matter intake & $57.0^{c}$ & $\begin{array}{l}82.2^{b} \\
83.8^{a}\end{array}$ & $85.3^{\circ}$ & $79.4^{2}$ & $87.1^{3}$ & $718^{5}$ & $\begin{array}{l}0.01^{*} \\
0.05^{*}\end{array}$ \\
\hline $\begin{array}{l}\text { Crude protein } \\
\text { intake } \\
\mathbf{X}\end{array}$ & $4.9^{c}$ & $\begin{array}{l}10.2^{b} \\
11.9^{a}\end{array}$ & $13.5^{\mathrm{a}}$ & $3.6^{\mathrm{t}}$ & $\begin{array}{l}10.8^{2} \\
11.1^{2}\end{array}$ & $11.4^{\mathrm{a}}$ & $\stackrel{0.01}{\text { NS }}^{*}$ \\
\hline
\end{tabular}

$(a, b, c)^{*}$ Means within the same subclass with different superscripts differ $(P<0.05$ or $<0.01)$

NS: Not Significant $(P>0.05)$.

** Data collected uptill the end of the Gth week (not includes in the specie mean) when the diet was discontinued because of the sudden death of some of the animaks on it. 
solutions of $\mathrm{H}_{2} \mathrm{SO} 4$ and $\mathrm{KOH}$. The tetermination of cyanide in some of the feeds was by the enzymatic method (Cooke, 1978)

\section{RESULTS}

\section{Experiment 1}

All the diets had high dry matter contents with a mean value of about $89 \%$ (Table 2). Crude protein levels increased from diet 1 (8.4\%) to diet 3 (15.6\%). Crude fibre levol decreased progressively from diet $1(34.0 \%)$ to diet $3(20.6 \%)$. Ether extract (EE) value in diet 1 (1.4\%) was less than those in diets 2 and 3. There was an increase in the ash contents of the diets from diet 1 to 3 . The highest concentration of nitrogen free extract (NFE) was contained in diet $1(51,4 \%)$. Energy values of the diets were $4.3,5.5$ and $5.7 \mathrm{kcal} / \mathrm{g}$ in diets 1,2 and 3 respectively.

Intake of nutrients by sheep was higher $(P<0.01)$ than the goats (Table 3). Likewise there were significant differences in nutrients among the diets. In the sheep, dry matter intake (DMI) was highest $(P<0.05)$ for diet 2. Crude protein and energy intakes were similar $(P>0.05)$ for diets 2 and 3 but different $(P<0.05)$ from diet 1 . Among the goats differences $(P<0.05)$ exist in DMI only with respect to diets 1 and 2. Protein and energy

TABLE 4: DIGESTIBIUTY OF NUTRIENTS BY SHEEP AND GOATS ON THE DIETS (\%)

EXPERIMENT 1

\begin{tabular}{|c|c|c|c|c|c|c|c|}
\hline $\begin{array}{l}\text { SPECIES } \\
\text { DIETS }\end{array}$ & 1 & SHEEP & 3 & 1 & $\begin{array}{l}\text { GOATS } \\
\end{array}$ & 3 & $\begin{array}{l}\text { LEVEL OF } \\
\text { SIGNIFICANCE }\end{array}$ \\
\hline DM Digestibility & $55.7^{\circ}$ & $\begin{array}{l}49.4^{\mathrm{c}} \\
57.7^{-}\end{array}$ & $67.9^{2}$ & $60.7^{a b}$ & $\begin{array}{l}52.7^{b} \\
59.9\end{array}$ & $66.4^{2}$ & $\begin{array}{l}0.05 * \\
0.05 \mathrm{NS}\end{array}$ \\
\hline CP digestibility & $44.8^{\mathrm{c}}$ & $\begin{array}{l}66.9^{6} \\
62.8\end{array}$ & $76.8^{\mathrm{a}}$ & $52.8^{b}$ & $\begin{array}{l}66.0^{2} \\
62.7\end{array}$ & $69.2^{2}$ & $\begin{array}{l}0.01^{*} \\
0.05 N \text {. }\end{array}$ \\
\hline $\begin{array}{c}\text { GE digestibility } \\
x\end{array}$ & $41.1^{\mathrm{c}}$ & $\begin{array}{l}48.9^{b} \\
51.1\end{array}$ & $63.3^{a}$ & $50.1^{b}$ & $\begin{array}{l}49.2^{b} \\
55.2\end{array}$ & $66.3^{2}$ & $\begin{array}{l}0.01^{\circ} \\
0.05 \mathrm{NS}\end{array}$ \\
\hline
\end{tabular}

EXPERIMENT 2

\begin{tabular}{|c|c|c|c|c|c|c|}
\hline $\begin{array}{l}\text { FPDCIB } \\
\text { DIEIS }\end{array}$ & $1 *$ & $\begin{array}{l}\text { SHEPP } \\
\mathbf{2}\end{array}$ & 3 & $1 *$ & GOATS & $\begin{array}{l}\text { LYVE OF } \\
\text { SICNIFICANCE }\end{array}$ \\
\hline DMI divestibility & - & $\begin{array}{l}60.5 \\
59.6^{b}\end{array}$ & 58.8 & - & 67.0 & $\begin{array}{l}0.05 N S \\
0.05 *\end{array}$ \\
\hline
\end{tabular}

$(a, b, c)^{*}$ Means within the same subclass with different superscripts differ $(P<0.05$ or $P<0.01)$

NS: Not Significant $(P>0.0 \dot{0})$

**: Experimentation with diet 1 (Expt. 2) was discontinued because of the sudden death of some of the animals. ieast on ciet 1.

There were differences $(P>0.05)$ between Sheep and goats in the lyestibility of dry matter, crude protein and energy (Table 4). Diet 3 was highly digestible for $\mathrm{CP}$, energy $(P<0.01)$ and DM $(P<0.05)$ than the other two diets among the sheep. In the goats, there 3. Howover, the DMD values for diets 1 and 2 were also sinilar $(P>0.05)$. Crude protein ligestibility of diet 1 and the energy digestibility of diet 3 were different $(P<0.01)$

Sheep on diet 3 had the highest $(P<0.05)$ weight gain (60.3g/day) (Table 5). Those on of 43.9 and $43.1 \mathrm{~g} /$ day respectively. Weight gain by the goats increased $(P<0.05)$ from diet 1 $(15.4 \mathrm{~g} / \mathrm{dat})$ to diet $3(28.4 \mathrm{~g} /$ day $)$. Sheep and goats on diet 3 had the best feed conversion efficiescy (FCE) (10.0 and 9.2\% respectively). The FCE of goats on diet 2 was similar $(P>0.05)$ to those on diet 3.

Experiment 2

The diets had a mean DM of about $90 \%$ (Table 2). Crude protein contents increased intakes were higher $(P<0.05)$ on diet 3 and were no significant differences $(P>0.05)$ in the Ary matter digestibility (DMD) of diets 1 and from the other two diets. diets 1 and 2 had similar $(P>0.05)$ weight gain 
from $8.9 \%$ in diet 1 to $15.9 \%$ in diet 3 . The crude fibre value was highest in diet $1(32.5 \%)$ and least in diet $3(22.4 \%)$. Diet 2 had the highest values of ether extract $(2.5 \%)$ and ash $(23.5 \%)$ and the least value of NFE (31.3\%). The hydrogen cyanide (HCN) contents of diets 1 and 2 were 16.7 and $19.3 \mathrm{mg} \mathrm{HCN} / \mathrm{kg}$ DM respectively. Dry matter intake (DMI) was higher $(\mathrm{P}<0.05)$ in sheep $\left(83.8 \mathrm{~g} / \mathrm{kg} \mathrm{w}^{0.75}\right)$ than in goats $\left(79.5 \mathrm{~g} / \mathrm{kg} \mathrm{w}^{0.75}\right.$ ) (Table 3). Goats and Nheep on diets 2 and 3 respectively had the highest DMI $\left(87.1\right.$ and $\left.85.3 \mathrm{~g} / \mathrm{kg} \mathrm{w}^{0.75}\right)$. There were no significant differences $(P>0.05)$ in the crude protein intake of sheep and goats (11.9 and $11.1 \mathrm{~g} / \mathrm{kg} \mathrm{w}^{0.75}$ respectively). The highest amount of protein was consumed on diet 3 while the least intake was on diet 1 in both species. Goats on diet 2 and 3 consumed crude protein almost to the same $(P>0.05)$ extent. (ioats digested dry matter better $(P<0.05)$ than the sheep (Table 4). Diet 3 was slighly more digestible than diet 2 in goats $(69.3$ versus $67.0 \%$ ) while diet 2 was better digested than diet 3 among the sheep (60.5 versus $58.6 \%$ ). However, the differences observed within the diets were not significant $(P>0.05)$. The dietary effect on liveweight changes was highly significant $(P<0.01)$ (Table 5 ). The highest weight gain was recorded by sheep on diet $3(112.4 \mathrm{~g} /$ day). Diet 2 and 3 in sheep had comparable $(P>0.05)$ feed conversion efficiency while that of diet 3 was the best among the goats.

\section{DISCUSSION}

The quantity and type of ingredients used in formulating the feeds influenced their chemical composition. In experiment 1, the levels of gliricidia leaves, brewers' dried grains (BDG) and poultry litter aided the relatively high concentration of protein in diet 3, whereas diet 1 contained low levels of protein rich ingredjents. Likewise in experiment 2 , concentrations of wheat offals, BDG, soyabean

\section{TABLE 5: LIVEWEIGHT CHANGES AND FEED EFFICIENCY OF SHEEP AND GOATS ON THE DIETS \\ EXPERIMENT 1}

\begin{tabular}{|c|c|c|c|c|c|c|c|}
\hline $\begin{array}{l}\text { SPECIES } \\
\text { DIETS }\end{array}$ & 1 & $\begin{array}{l}\text { SHEEP } \\
\mathbf{2}\end{array}$ & 3 & 1 & $\begin{array}{l}\text { GOATS } \\
2\end{array}$ & 3 & $\begin{array}{l}\text { LEVGI OR } \\
\text { BIGNIFICANCE }\end{array}$ \\
\hline $\begin{array}{l}\text { Average liveweight } \\
(\mathrm{kg})\end{array}$ & 17.1 & 17.3 & 17,9 & 9.3 & 8.6 & 9.8 & \\
\hline $\begin{array}{l}\text { Liveweight changes } \\
(\mathrm{g} / \mathrm{day})+\end{array}$ & $43.9^{\circ}$ & 43.1. & $60.3^{\circ}$ & $15.4^{*}$ & $23.2^{b}$ & $28.4^{*}$ & $0.05^{*}$ \\
\hline Dry matter intake & 512.1 & 623.1 & 600.5 & 204.6 & 225.0 & 263.6 & \\
\hline $\begin{array}{l}\text { Feed efficiency }+ \\
\text { (Feed/gain) (\%) }\end{array}$ & $11.6^{6}$ & $14.4^{\mathrm{a}}$ & $10.0^{\mathrm{c}}$ & $17,1^{\circ}$ & $9.7^{b}$ & $9.2^{b}$ & $0.05^{*}$ \\
\hline
\end{tabular}

EXPERIMENT 2

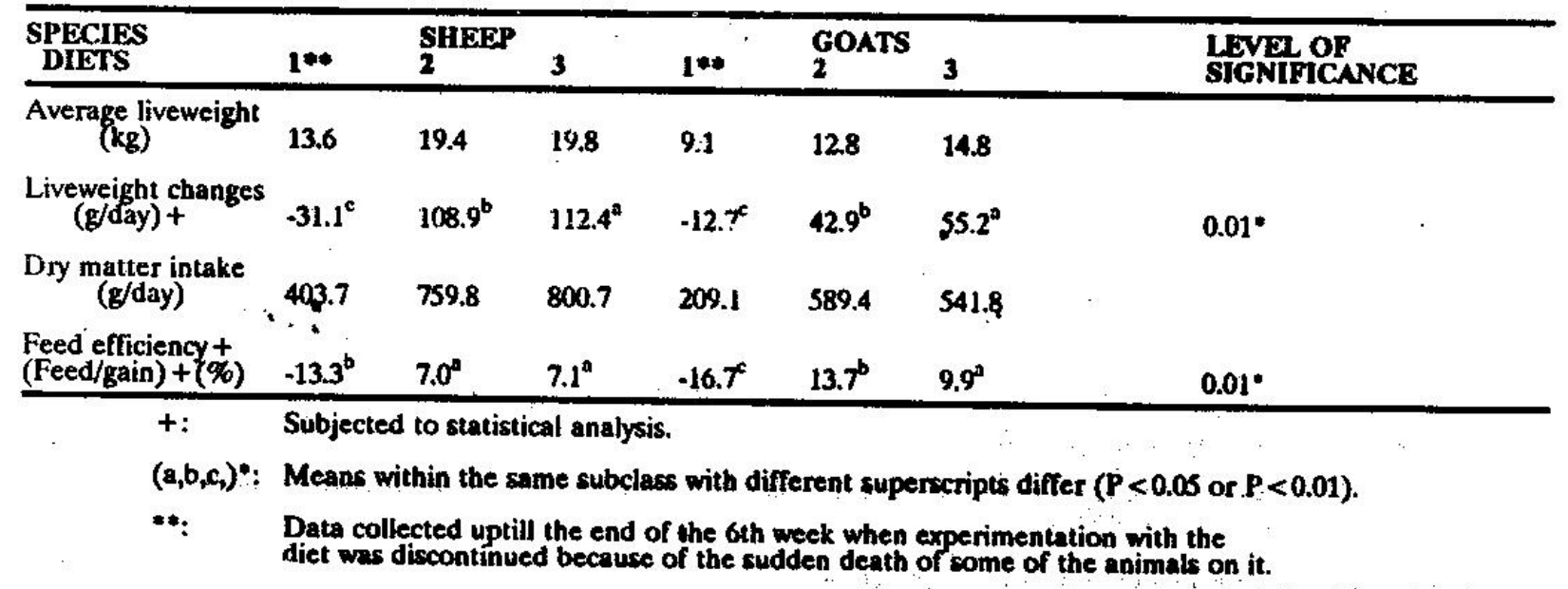


hull and palm kernel cake boosted the protein level of diet 3. The preponderance of ligno-cellulose containing ingredients e.g.maize cob and rice husk in diet 1 of both experiments was responsible for their high crude fibre levels. The large volume of the digestive tract of the sheep, especially the reticulorumen, has the capacity to retain more feed than that of goats. This could $b$ : responsible for its relatively higher intake of feed and nutrients recorded.

High crude protein content of a feer' stimulates appetite and feed intake (Tolkamp, 1988). Thus it can be deduced that more of a diet with high crude protein (CP) content would be consumed compared with another diet low in CP content. This works by providing rumen degradable nitrogen for micro-organisms to build their body protein. The low feed intake of diets with low CP contents would be accentuated by high crude fibre diet to be digested. This increases its retention time in the reticulorumen (Orskov and Ryle, 1990) thereby depressing the intake of more feed. The higher digestibility of DM in goats relative to the sheep can be attributed to the higher feed intake in sheep. Higher feed intake results in a laster rate of passage of digesta, from the reticulo-rumen. This reduces the rate of passage of feed via the reticulo-rumen to allow for degradation, hence lowering its digestibility (McDonald et al., 1988). The improvement in the DM digestibility of goats over sheep is supported by another study (Adebowale, 1989) where $\mathrm{NaOH}$-treated maize cobs at levels between 0 to $40 \%$ in their diet. However, when Echinochloa stagnina was fed as the sole feed, goats and sheep exhibited similar patterns in their ability to digest the various nutrients, except for ADF in the forage (Adebowale, 1988).

High protein contents of diets 2 and 3 play significant role in improving the digestibility of nutrients over those of diet 1 . This is supported by McDonald et al (1988) that the concentration of $C P$ in a feed affects it: digestibility. High fibre content inhibits digestibility. Thus diet 1 with high fibre could have contributed to its low digestibility. The rate of microbial colonization of a feed with high fibre content is lower (Silva and Orskov, 1988) compared to another with low fibre. Thus this reduced its degradation.

The better weight gain of sheep reflected the higher potentials of WAD sheep over WAD goats in body weight gain. The liveweight gains for sheep and goats were quite low compared with those reported elsewhere (Adebowale, 1989). However, the inclusion of $+0 \%$ untreated maize cots in the diets of the jats (Adebowale, 1989) resulted in $24.9 \mathrm{~g} /$ day weight gain, which is similar to those for goats on diet 2 and 3 (Experiment 1 ) in this report. The performance recorded for sheep on diets 2 and 3 (Experiment 2) outstripped the weight gain obtained by Adebowale (1989); Adeleye (1980) and Adegbola et al (1990).

Availability of digestible protein and energy reflected by the relatively lower fibre levels, provided ready nutrients for the synthesis of body tissues in the lower gut. This could be responsible for the higher weight gains and efficiency of feed utilization of animals on diets 2 and 3 over those on diet 1. The wide discrepancies in the liveweight gains of the animals between Experiments 1 and 2, despite the similarity in the protein levels of the respective diets, could, among other factors, be due to the simplistic approach of using crude protein contents to determine protein requirement. It would be better to adopt the method of apportioning dietary protein requirements in the forms of rumen degradable protein and rumen bypass protein is it is done in United Kingdom (ARC, 1984) and United States of America (N.R.C., 1985). This would involve the determination of the degradability of local feeding stuffs.

The weight loss by animals on diet 1 (Experiment 2) could be attributed to the probable presence of some anti-nutritional factors in the diet. In the course of the experiment, 2 goats and 1 sheep on diet 1 (Experiment 2) died. The death occurred between the 4th and 6th weeks of the study. Since all the dead animals were on a particular diet, dietary effect was suspected as the 
causative agent of death. Thuis experiment with diet 1 was discontinued and the remaining animals on it were released from the pens. The characteristic patterns preceding death among the animals were bloated stomach and reduction in feed intake. Hydrogen cyanide (HCN) poison from cassava peels was at first suspected. Cyanide analysis of diets 1 and 2 containing cassava peels revealed that they had values less than $20 \mathrm{mg} \mathrm{HCN} \mathrm{kg}$ sample (Table 2). This is within the limit of $50 \mathrm{mg} \mathrm{HCN} / \mathrm{kg}$ classified as non-toxic (Bolhuis, 1954). The dried nature of the feeds also implied that the HCN contents would have been reduced during the drying process. The likely cause of the death of the animals could then be mycotoxins.

In conclusion small ruminants were able to subsist and make appreciable weight gains on some crop residue-based diets. The combination of feed ingredients in the second experiment gave better weight gain than on the first experiment. The performance of animals on diets 2 and 3 (Experiment 2) were comparable for most of the parameters recorded. More studies should be executed to know the optimal utilization of other different combinations of crop residues as livestock feed. Formulation of diets with crop residues reduces competition for conventional leed ingredients and provides needed nutrients especially during the dry season when available green forage is low in quality and quantity. Transportation and availability of the feed in mash form would be of tremendous advantage to live stock farmers.

\section{ACKNOWLEDGEMENT}

The authors are grateful to the Presidency, Federal Government of Nigeria for the facilities provided for this work through the first author who was a member of the Presidential Task Force on Alternative Formulation of Livestock Feeds.

\section{REFERENCES}

ADEBOWALE, E.A. (1981) The feeding value of cowpea husks (Vigna unguiculata Walp) in rations for goats Tumialba 31: 141 - 145
ADEBOWALE, E.A. (1982), Growth economics and carcass characteristics of goats fed maize cobs, yam peels and plantain peels diets. Ind. J. Anim. Sci. 52: 285 - 292.

ADEBOWALE, E.A. (1985). Response of WEs? African dwarf Sheep and goats fed maize straw treated with local alkali. Nig. J. Anim. Prod. 12: 137 - 149.

ADEBOWALE, E.A. (1988): Performace of young West African Dwarf goats and sheep fed on an aquatic macrophyte Echinochloc stagnina, Small Rumin. Rs: 1: 167-173

ADEBOWALE, E.A. (1989): Response of West African Dwarf sheep and goats fed maize cobs treated with different concentrations of caustic soda. Trop. Agric. (Trinidad) 66: 213 $-216$

ADEGBOLA, A.A., SMITH, O.B and OKEUDO, N.J. (1990): Response of West African Dwarf sheep fed cassava pees and poultry manure based diets. In: utilixation of research results on forages and agricultural by-product materials as animal feed resources in Africa. PP. 357 - 366. (Eds. Dzowela B.H., Said A.N.; Wendem Agenuhu A. and Kategile, H.H.) ILCA Addis Ababa.

ADELEYE, I.O.A. (1980): The effect of $\mathrm{NaOH}$ spray treatment of maize cobs on consumption and digestibility by the West African Dwarf Sheep. Nig. J. Anim. Prod. 7: $132-137$

AGRICULTURAL RESEARCH COUNCIL (1984): The Nutrient Requirements of Ruminant Livestock, Supplement No. 1. Commonwealth Agricultural Bureaux, Farnham Royal, London.

ALHASSAN, W.S. (1988) Studies on untreated crop residue utilization in red sokoto goats. In: Goat Production in the humid tropics. -(Eds. O.B. Smith and H.G. Bosman) Pudoc. Wageningen. pp. $62-66$

ASSOCIATION OF

ANALYTICAL CHEMISTS (1980): OFIAL methods of analysis (13th (1980): Official methods of analysis (13th edition). A.O.A.C. Washinton D.C.

BHATTACHARYYA, A.N. and TAYLOR, J.C. (1975): Recycling animal waste as a feed stuff. A Review.J. Anima. Sci. 41: 1438 - 1457

BOLHUIS (1954): The toxicity of cassava roots. Neth. J. Agric. Sci. 2: 176 
COOKE, R. (1978): Cyanide assay by manual method J. sci. Food Agric. 29: 345 - 352.

JACKSON M.G. (1977) Review article: The alkali treatment of straws Anim. Feed Sci. Technol. 2: 105 - 130

LENG R.A. (1990): Factors affecting the utilization of poor quality forages by ruminants particularly under tropical conditions. Nut. Res. Rev. 3: 277 - 303.

MCDONALD P. , EDWARDS R.A. and GREENHALGH J.F.D. (1988): Animal Nutrition (4th edition). Longman Scientific and technical, England.

NATIONAL RESEARCH COUNCIL (NRC) (1985): Ruminant Nitrogen Usage. National Academy of sciences. Washinton DC

NICHOLSON J.W.G. (1984): Digestibility, nutritive values and feed intake. Chapter 12 . In: Straw and othe fibrous feed (F. Sundstol and E., Owen, Editors) Elseiver, Amsterdam.

ORSKOV E.R. and RYLE M. (1990): Energy Nutrition in Ruminants. Elsevier Applied Science, London.

PRESTON T.R. (1986). Strategic supplementation to optimise rumen function and the balance of absorbed nutrients in ruminants fed largely on crop residues. In:
Towards optimal feeding of agricultural by-products to livestock in Africa (T.R. Preston and M.Y. Muwanyakpa Eds.) ILCA Addis Ababa. PP: 167 - 180

SILVA A.T. and ORSKOV E.R. (1988): The effect of Five different supplements on the degradation of straw in sheep given untreated barley straw. Animal Feed sci. Technol. 19: 289 - 298

STEEL R.G.D. and TORRIE J.G. (1980): Principles and Procedures of statistics. (2nd Edition). McGraw Hill Books Company Inc. New York, Toronto and London.

TAIWO A.A., ADEBOWALE E.A. GREENHALGH J.F.D. and A.O. AKINSOYINU (1992): Effect of urea treatment on chemical composition and degradation characteristics of some crop residues. Nig. J. Anim. Prod. 19: 25-36.

TOLKAMP B: (1988): Feed intake regulation and small ruminants. In: Goat production in the humid tropics (Eds. O.B. Smith and H.G. Bosman) Pudoc Wageningen. pp: 67 - 75. 